\title{
Serological Relationship among Chrysanthemum Mild Mottle Virus, Tomato Aspermy Virus and Cucumber Mosaic Virus
}

\author{
Hiroshi Tochinara* \\ 杤原比呂志*：キク微斑ウイルス, TAV および \\ $\mathrm{CMV}$ 相互の血清学的関係
}

Tomato aspermy virus (TAV), originally described by Blencowe and Caldwell (1949)1), causes a severe disease of tomato characterized in part by suppression of seed formation after infection. The virus has since then been reported by several authsrs as widespread in chrysanthemum. They referred viruses derived from chrysanthemum that are similar in many respects to cucumber mosaic virus (CMV) to TAV, but there are only limited agreement with respect to host range and symptoms, except that none of these viruses infect cucumber systemically (see references ${ }^{2-5}$ ) for reviews of the conflicting literature).

Serological relationship between TAV and CMV has also been a controversial subject ${ }^{2,5-11) .}$ Lawson (1967) showed that CMV is serologically related to TAV-B (British type culture of TAV), but is not related to three other TAV isolates from chrysanthemum. Viruses which are similar to CMV in many respects excepting that they do not systemically infect cucumber had so far been grouped under TAV, but he suggested that TAV-B should be tentatively grouped separately from those isolates from chrysanthemum not serologically related to CMV. A virus which is similar in many respects but serologically not related to CMV is widespread in chrysanthemum in Japan, and was tentatively named chrysanthemum mild mottle virus (CMMV)5). Some properties of this virus was also described 5 .

The present report deals with serological relationship of this virus with TAV isolates from Europe and America.

Antisera against TAV strain 2, TAV Brierley's strain, and chrysanthemum aspermy virus were kindly supplied by M. Hollings (Glasshouse Crops Research Institute, England), K. A. Kimble (Department of Plant Pathology, University of California, U.S.A.) and F. Marani (Istituto di Patologia Vegetale, Dell' Universita, Italia), respectively.

Materials and Methods: Viruses used were CMMV, CMV-Y (yellow strain)5), and two CMV

* Institute for Plant Virus Research, Chiba, Japan. 植物ウイルス研究所

1) Blencowe, J. W. and Caldwell, J. (1949). Ann. appl. Biol. 36: 320-326.

2) Grogan, R. G., Uyemoto, J. K. and Kimble, K. A. (1963). Virology 21 : 36-42.

3) Lawson, R. H. (1967). Virology 32 : 357-362.

4) Mink, G. I. (1969). Phytopathology 59 : 1889-1893.

5) Tochihara, H. (1970). Ann. Phytopath. Soc. Japan 36: 1-10.

6) Govier, D. A. (1957). Ann. appl. Biol. 45: 62-73.

7) Hollings, M. and Stone, O. M. (1965). Ann. appl. Biol. 56: 87-98.

8) Kahn, R. P. and Scott, H. A. (1964). Phytopathology 54 : 360-362.

9) Marani, F. (1969). Phytopath. Med. 8: 142-149.

10) Noordam, D. (1952). Tijdschrift over Plantenziekten $58: 121-190$.

11) van Slogteren, D. H. M. (1958). Proc. 2nd Intern. Sci. Tobacco Congr. Brussels (1958). pp. 144149. (Advan. Virus Res. 12: 251). 
isolates CMV-P and CMV-L obtained from butter-bur (Petasites japonicus Miq.) and lettuce (Lactuca sativa Linn.), respectively. Antisera used were TAV strain 2 antiserum (common European and American type virus, titer of the antiserum in homologous precipitin tube test being $1 / 1024$ according to Hollings' personal letter), TAV Brierley's strain antiserum (titer being 1/256 according to Kimble's personal letter), and chrysanthemum aspermy virus antiserum (titer unknown), and antisera gainst CMMV and CMV-Y previously described ${ }^{5)}$. CMMV and CMV-Y antigens were purified from inoculated leaves of tobacco as previously described ${ }^{5}$. The purified virus preparations were mixed with an equal volume of glycerin and stored at about $-10 \mathrm{C}$ until use.

Serological comparisons among CMMV, CMV-Y and three TAV antisera were made in agar gel double diffusion tests at $4-8 \mathrm{C}$. The gel was $1 \%$ agar in $0.02 \mathrm{M}$ phosphate buffer, pH 7.2 , containing $0.85 \% \mathrm{NaCl}, 0.0025 \mathrm{M} \mathrm{Na}$-EDTA and $0.01 \%$ sodium azide, and an octagonal arrangement of wells of $8 \mathrm{~mm}$ diameter around a central well of the same size was used in all tests. The distance between the edge of the central well and every surrounding well was $8 \mathrm{~mm}$. The wells were filled with antigens of $0.3 \mathrm{ml}$ at concentration of $2 \mathrm{mg} / \mathrm{ml}$ or antisera of $0.3 \mathrm{ml}$ which were diluted to $1: 5$ (CMMV antiserum, CMV-Y antiserum), 1:2 (TAV strain 2 antiserum) or $1: 1$ (TAV Brierley's strain antiserum, chrysanthemum aspermy virus antiserum), respectively.

Results and Conclusion: CMMV reacted distinctly with each of the three TAV antisera, forming a specific zone of precipitate in agar gel. The precipitin band formed by the reaction of CMMV and chrysanthemum aspermy virus antiserum was more faint compared with the cases of the other

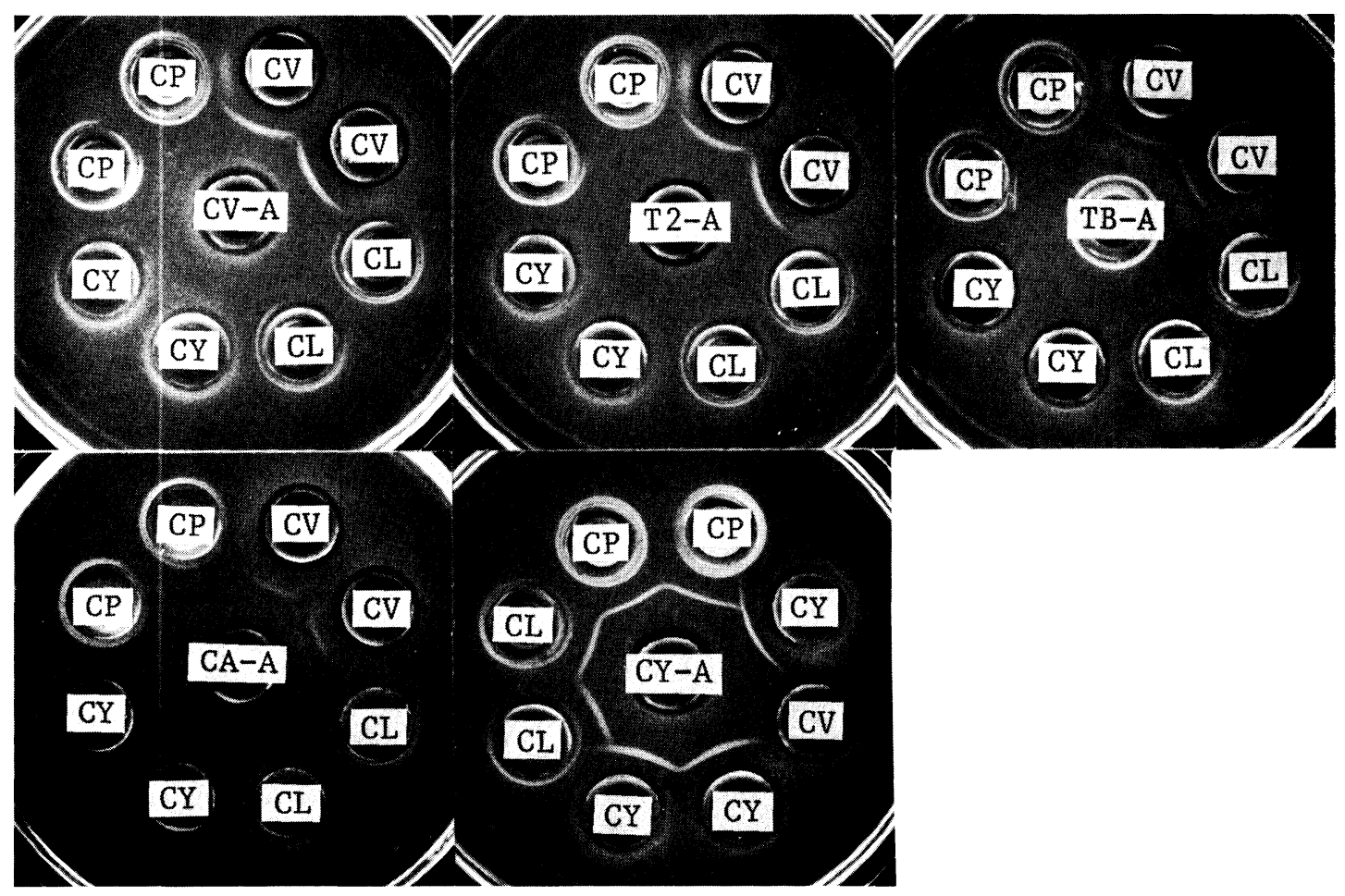

Fig. 1. Agar gel diffusion tests among CMV, CMMV and TAV $\mathrm{CY}=\mathrm{CMV}-\mathrm{Y} ; \mathrm{CP}=\mathrm{CMV}-\mathrm{P} ; \mathrm{CL}=\mathrm{CMV}-\mathrm{L} ; \mathrm{CV}=\mathrm{CMMV} ; \mathrm{CY}-\mathrm{A}=\mathrm{CMV}-\mathrm{Y}$ antiserum ; $\mathrm{CV}-\mathrm{A}=\mathrm{CMMV}$ antiserum ; $\mathrm{T} 2-\mathrm{A}=\mathrm{TAV}$ strain 2 antiserum ; $\mathrm{TB}-$ $\mathrm{A}=\mathrm{TAV}$ Brierley's strain antiserum ; $\mathrm{CA}-\mathrm{A}=$ chrysanthemum aspermy virus antiserum 
three antisera. This antiserum possibly had a lower titer than the other antisera. In contrast, no reaction was observed in tests with the three CMV isolates and the three TAV antisera. CMV-P and CMV-L do not infect chrysanthemum, although the viruses were isolated from plants belonging to Compositae. Cucumber plants inoculated with them showed faint chlorotic spot symptoms on some leaves for a few days, which then became masked, or in other cases, no infection. As these viruses have some resemblances to $\mathrm{TAV}-\mathrm{B}$ in infectivity to cucumber plant, they were included in the tests. As can be seen in Fig. 1, between CMV-Y and CMV-P or between CMV-Y and CMV-L, the precipitin bands show a distinct spur reaction, indicating some serological differences of CMV-Y from the other two isolates. There was no serological reaction between the CMV isolates and CMMV, or CMV isolates and the three TAV antisera.

As no antiserum against TAV-B type isolate has been available, serological relationship between CMMV and TAV-B remains obscure.

In order to determine serological relationship in agar gel diffusion tests, it is necessary to use 2 antigens against 1 antiserum. In this experiment, TAV antisera only were used but not TAV for antigen. It is therefore unable to decide whether or not CMMV and the three TAV isolates are serologically distinguishable, but they appear to be very closely related and CMMV which is widespread in chrysanthemum in Japan seemed to belong to the group of Lawson's chrysanthemum virus $^{3)}$ in Europe and America.

(Received September 25, 1972) 